\title{
Xanthogranulomatous Pyelonephritis as an Invasive Infiltrative Process: Case Report and Review of the Literature
}

\section{Pielonefrite Xantogranulomatosa como um Processo Infiltrativo Invasivo: Relato de Caso e Revisão de Literatura}

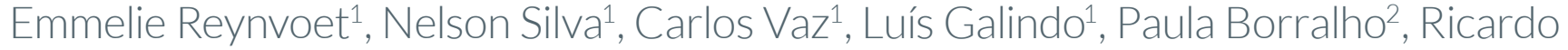
Girão1*

Corresponding Author/Autor Correspondente: Emmelie Reynvoet [emmeliereynvoet@hotmail.com] Travessa do Castro No 3, 1350-070 Lisbon, Portugal

\section{ABSTRACT}

INTRODUCTION: Xanthogranulomatous pyelonephritis is a rare inflammatory disease associated with chronic infection and obstruction and a typical pathological picture.

CASE REPORT: A 63-year-old woman was referred to our outpatient clinic with complaints of general malaise, diffuse abdominal discomfort, weight loss and recurrent urinary tract infections. An abdominal mass could be palpated in the left flank. Laboratory investigations revealed anaemia, leucocytosis and leukocyturia. Imaging showed multiloculated retroperitoneal mass involving two upper thirds of the left kidney and a massive stone in the sinus of the left kidney.

The patient was treated with an 'en bloc' resection of the left kidney, pancreas tail, spleen and colon transversum. On microscopy, the renal parenchyma showed atrophic with inflammation, necrosis and a widespread infiltration of lipid filled macrophages (xanthoma cells).

DISCUSSION: The discussed case is a typical presentation of xanthogranulomatous pyelonephritis. The patient was treated by an extensive resection of the involved organs and recovered well.

KEYWORDS: Pyelonephritis, Xanthogranulomatous 


\section{RESUMO}

INTRODUÇÃO: A pielonefrite xantogranulomatosa é uma doença inflamatória rara associada a uma infeção crónica, obstrução e uma imagem patológica típica.

CASO CLÍNICO: Uma mulher de 63 anos foi referenciada à nossa consulta de ambulatório por fraqueza geral, um desconforto abdominal difuso, perda de peso e infeções do trato urinário recorrentes. Conseguia-se palpar uma massa abdominal no flanco esquerdo. Investigações laboratoriais revelaram anemia, leucocitose e leucocitúria. Os estudos de imagens mostravam uma massa retroperitoneal multiloculada envolvendo os dois terços superiores do rim esquerdo e um cálculo de grandes dimensões no seio do rim esquerdo.

A paciente foi tratada com uma ressecção "em bloco" do rim esquerdo, da cauda do pâncreas, baço e cólon transverso. Na microscopia o parênquima renal estava atrófico e com um processo inflamatório, necrose e uma infiltração difundida de macrófagos preenchidos por lípidos (células xantoma).

DISCUSSÃO: O caso discutido é uma apresentação típica da pielonefrite xantogranulomatosa. A paciente foi tratada com uma ressecção extensa dos órgãos envolvidos e teve uma boa recuperação.

PALAVRAS-CHAVE: Pielonefrite Xantogranulomatosa

\section{INTRODUCTION}

Xanthogranulomatous pyelonephritis (XQP) is a rare disease with a challenging diagnostic and therapeutic approach. It is an inflammatory disease associated with chronic infection and obstruction. XGP has a typical pathological appearance; a granulomatous inflammatory process with lipid filled macrophages (xanthoma cells). ${ }^{1}$ It is often mistaken as a malignancy or another inflammatory disease such as sarcoidosis, amyloidosis, invasion and destruction of the tissue of the kidney as well of the adjacent organs, e.g. the pancreas, spleen and even colon or duodenum is seen. An adequate treatment, as is nephrectomy in most cases, can be very challenging. ${ }^{2}$

\section{CASE REPORT}

A 63-year-old woman was referred to our outpatient clinic at CUF Infante Santo Hospital, Lisbon. Six months ago, she consulted the general practitioner for the first time. She complained of general malaise, diffuse abdominal discomfort and weight loss (25 kg in 5 months). She had two episodes of hematuria and she had frequently dysuria. On the first clinical examination, she was in good general condition (no fever, normal tension and heart rate), but an abdominal mass could be palpated in the left flank. In the past, she had recurrent urinary tract infections. Besides, there was no important family or medical history.

\section{INVESTIGATIONS}

- Routine blood analysis showed an anemia (Hb $7.4 \mathrm{~g} /$ $\mathrm{dL}$ ) with leukocytosis $\left(17 \times 10^{9}\right)$ and elevated erythrocytic sedimentation rate. Serum creatinine was elevated (1.5 mg/dL). Urinalysis showed leucocyturia and an Escherichia coli could be isolated.
- On the abdominal ultrasound, the radiologist describes a hypoechogenic and heterogeneous image at the pancreas tail, in contact with the spleen and the left kidney, with a lobulated aspect and a diameter of $12 \mathrm{~cm}$.

- A computed tomography (CT) - scan was performed as can be seen in Fig. 1. A multiloculated retroperitoneal mass can be seen, with a size of $9.6 \times 12.8 \times 7.7$ $\mathrm{cm}$ with irregular borders involving two upper thirds of the left kidney. The left kidney has a massive stone in the sinus with about $5 \mathrm{~cm}$ in length. Retroperitoneal adenopathy is described.

- An ultrasound guided puncture of the pancreas tail was performed. Anatomopathology shows an area of necrosis with intense inflammation. A mixture of inflammatory cells is seen with histiocytic cell aggregates. No evidence for neoplastic tissue. These aspects were compatible with the hypothesis of xanthogranulomatous inflammation.

With this history and further investigations; blood analysis, imaging (ultrasound and CT) and biopsy, the diagnosis of XGP was revealed. The patient was referred to our centre for surgery.

\section{TREATMENT}

Between the time of the first consultation and the surgery, the clinical situation of the patient aggravated. She was admitted once on the emergency ward for blood transfusion. She had increasing abdominal pain, anorexia and fatigue.

\section{SURGERY}

Two weeks preoperatively she received standard splenectomy vaccinations (pneumococci, meningococci, haemophilus influenza B). 
She was admitted to the hospital at the day of the surgery. Start Hb was $7.4 \mathrm{~g} / \mathrm{dL}$. She received prophylactic antibiotherapy (cefazoline $2 \mathrm{~g}$ ).

A median laparotomy was performed. First, the colon transversum was lifted and the retroperitoneum was incised. The retroperitoneal tissue appealed edematous and thickened. The inferior mesenteric vein was ligated. Thereafter the left renal artery and vein were isolated. Secondly, the bursa omentalis was opened and a view on the pancreas was obtained. The pancreatic tissue was inflammatory and the section plane of the pancreas was determined. Thirdly, the splenic artery was isolated and ligated. The spleen was mobilized by section of the splenic ligaments. We decided to remove also a part of the colon at the left flexure, as it was clearly involved in the inflammatory process. Finally, the left kidney was mobilized and the renal vessels and ureter were ligated. The pancreas was transected and the piece could be removed 'en bloc'. A side to side coli-colic anastomosis was performed. After thorough rinsing the abdomen was closed. One drain was left (Fig. 2).

During surgery, the patient was hypovolemic and needed transfusion (4 units of erythrocytes). Postoperatively she was admitted to the ICU and kept intubated for 24 hours. Diuresis maintained well with adequate fluid management. No postoperative need for adrenaline. Discharge to the room on the third postoperative day. No complications during hospital stay and the patient was discharged after eight days. Two weeks later, the patient was seen on the outpatient clinic and is recovering well.

\section{PATHOLOGY}

Macroscopic pictures are shown in Fig. 3. A lot of purulent areas are seen in the kidney and the spleen. The pyelocaliceal system is dilated and contains a lot of stones. The kidney parenchyma is atrophic. Microscopically (Fig. 4), the renal parenchyma has an intense atrophy with an extensive inflammation; abscesses are seen, necrosis and a widespread infiltration of macrophages with vacuole - containing cytoplasm. The inflammatory process invades the perirenal fat, the capsule of the spleen, the serosa of the colon and the pancreas.

\section{DISCUSSION}

Xanthogranulomatous pyelonephritis (XGP) is a rare but serious disease with a challenging diagnosis and treatment. It was first described by Schlagenhaufer in 1916 and since then not more than 300 cases have been re-
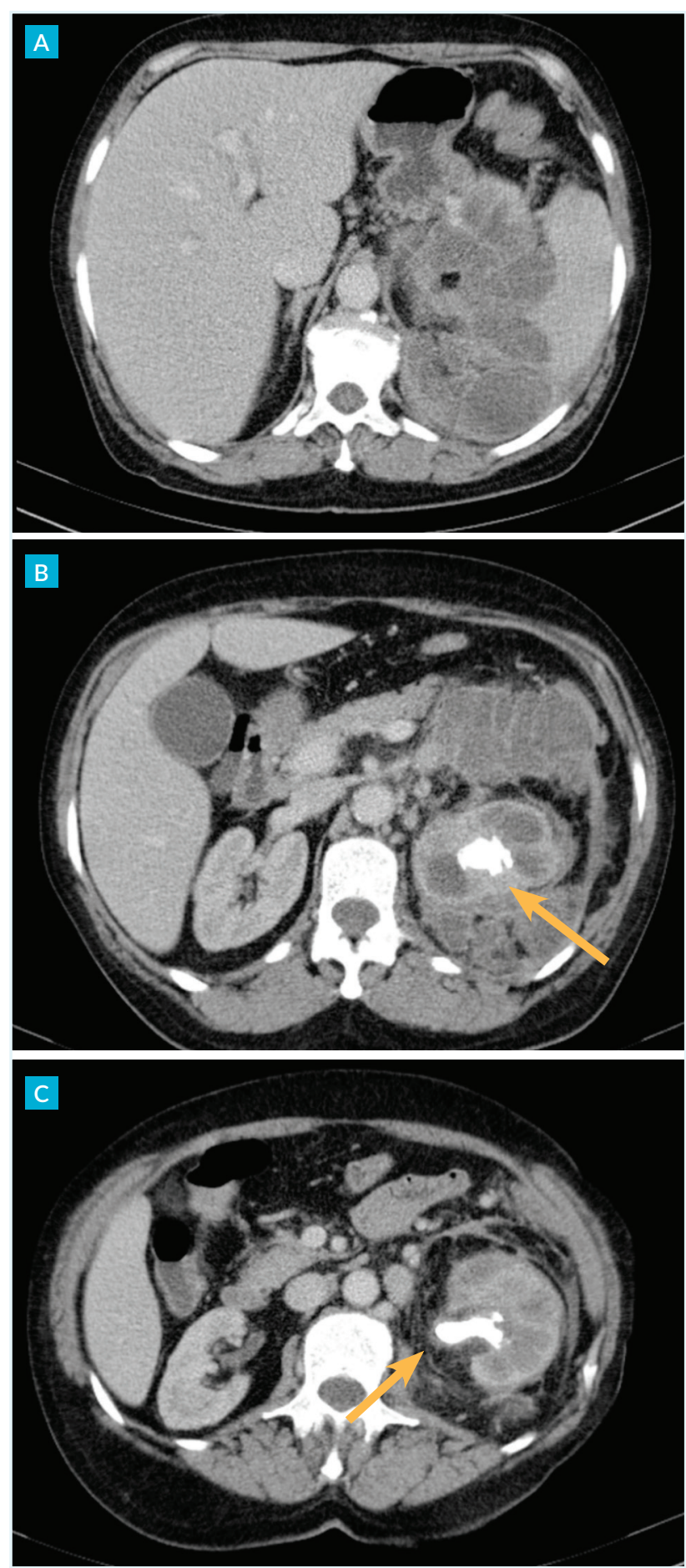

FIGURE 1. CT scan preoperatively. 1-A) A big multiloculated mass is seen retroperitoneally. 1-B) The kidney has a cystic aspect with a very big stone in the sinus (yellow arrow) 1-C) The large stone (yellow arrow) is seen with an explicit retroperitoneal inflammation.

ported. ${ }^{3}$ It is named because of its pathological appearance; that of a granulomatous inflammatory process with lipid filled macrophages, which appear yellow, hence 'xantho' which is Greek for yellow. ${ }^{4}$

XGP is a chronic inflammatory disease characterised by tissue destruction and invasion of the renal parenchyma. It usually develops during a prolonged kidney in- 


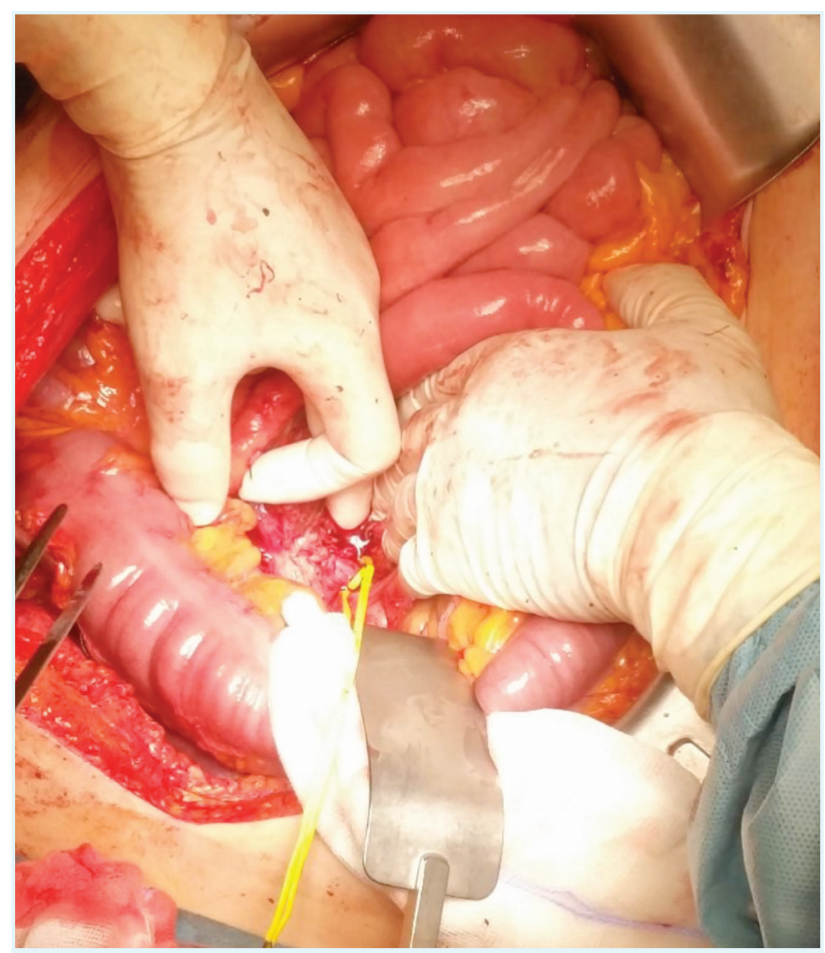

FIGURE 2A. Isolation of the left renal vein.

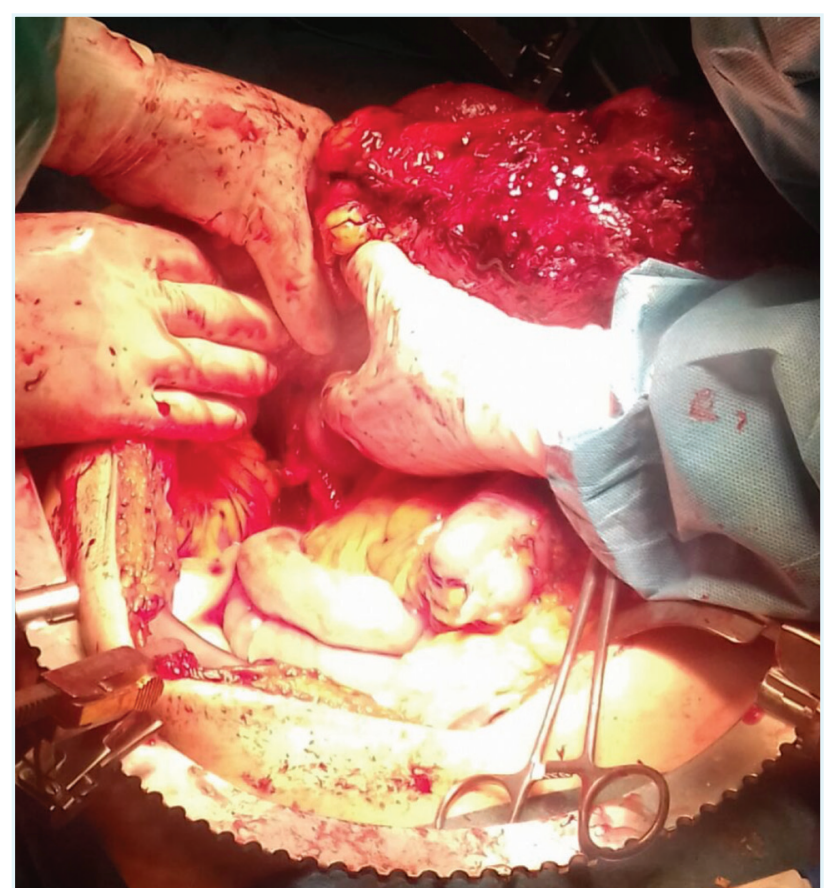

FIGURE 2B. Removal of the piece "en bloc": left nephrectomy, splenectomy, distal pancreatectomy, partial colectomy.

fection by an obstructive disease due to renal stones, in casu a very large one (Fig. 1B/1C). The most commonly isolated organisms are Proteus spp. and Escherichia coli. ${ }^{5}$

Most cases are unilateral and usually, the affected kidney is not functional. In most cases it presents as a diffuse process, however some cases (20\%) have only a focal presentation. XGP is four times more common in woman than in men and typically presents in the fifth and sixth decades of life.
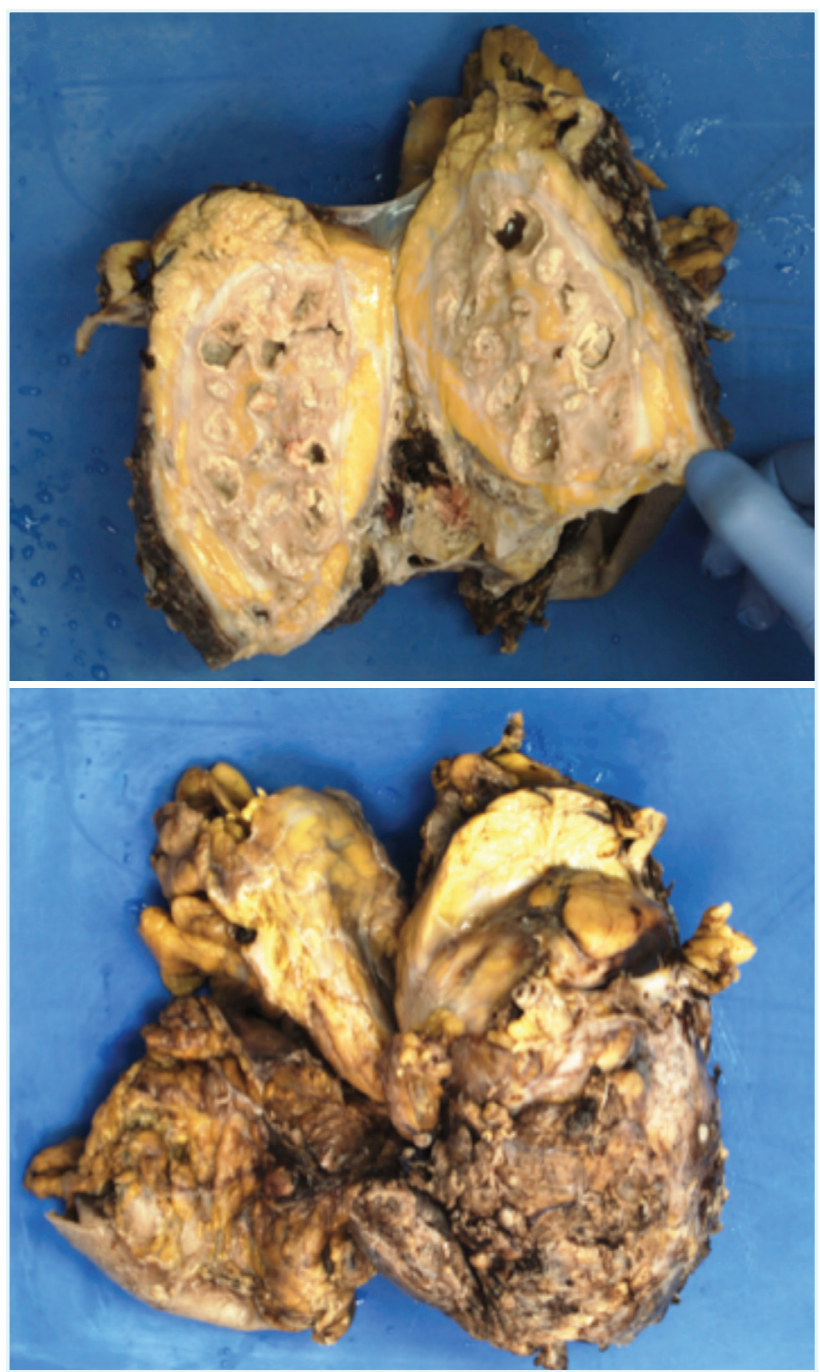

FIGURE 3. Macroscopic findings. Abscesses can be seen as holes with a dilated pyelocaliceal system.

It is rarely seen in the paediatric population; however, it is an important reason for nephrectomy in children. It is more seen in boys, usually before the age of 8 years and is more due to congenital factors than to obstructive diseases.

Commonly, XGP presents as general malaise, flank pain, fever, anorexia and weight loss. Blood test show nonspecific inflammation and urine analysis may reveal a urinary tract infection. Laboratory results showed anaemia in $71.4 \%$ of cases, leucocytosis in $61.9 \%$, and pyuria in $81.0 \% .^{5}$

One-third of the patients present with complications such as a psoas abscess, a paranephric abscess, a nephrocutaneous fistula or a nephrocolonic fistula. ${ }^{6}$

US examination shows an enlarged kidney with loss of normal renal architecture and often centrally a big stone. CT scan shows the renal tissue replaced by several cysts, rounded low-density areas surrounded by a rim of contrast medium. The calyces are dilated. Classically, 
a triad exists: unilateral enlarged kidney, renal pelvis stone, and a non-functioning kidney. The multiloculated appearance can appear like the paw of a bear, sometimes referred to as the bear's paw sign. ${ }^{7}$

XGP is often confused with renal carcinoma. It must however also be differentiated from renal parenchymal malakoplakia, leyomyosarcoma, sarcoïdosis, amyloïdosis, interstitial nephritis. In the present case, a mucinous cyst of the pancreas was suggested on the first radiological investigations.

In a review of 41 patients, preoperatively the diagnosis of XGP was only made in $22 \%$ of the patients. Other patients were thought to have nephrolithiasis (31.7\%), pyonephrosis (31.7\%), perinephric abscess (5\%) or a renal tumour (5\%) and the diagnosis could only be made after anatomopathological investigation of the extracted tissue sample. ${ }^{8}$ Therefore, a biopsy is mandatory to confirm the diagnosis of XGP preoperatively.

Although XGP is a rarely seen pathologic image, it has a very typical appearance. The essential feature is the presence of lipid-laden macrophages. In spite of the unusual and often impressive appearance of XGP, it may still be confused by renal cell carcinoma. The cytological material in adenocarcinoma consists of neoplastic cells arranged in rather coherent groups. In contrast, the cells of XGP are more loosely arranged. In adenocarcinoma, the cytoplasm is pale, the nuclei are usually small and round exhibiting a variety of sizes and the PAS stain is invariably positive. In XGP the cytoplasm is yellowish, demarcated and granular. The nuclei show a little variety in size. Generally, giant cells are present, staining positive for PAS.

\section{CONCLUSION}

We present a case of a 63-year-old woman with xanthogranulomatous pyelonephritis. XGP is an uncommon inflammation of the renal parenchyma that occurs in the presence of chronic obstruction and suppuration. We were able to diagnose the condition correctly by the clinical presentation, radiologic images and biopsy. Due to the invasively infiltration of the disease we opted for the open approach and we were proven right preoperatively with the kidney densely adherent to surrounding structures; the spleen, colon and pancreas.
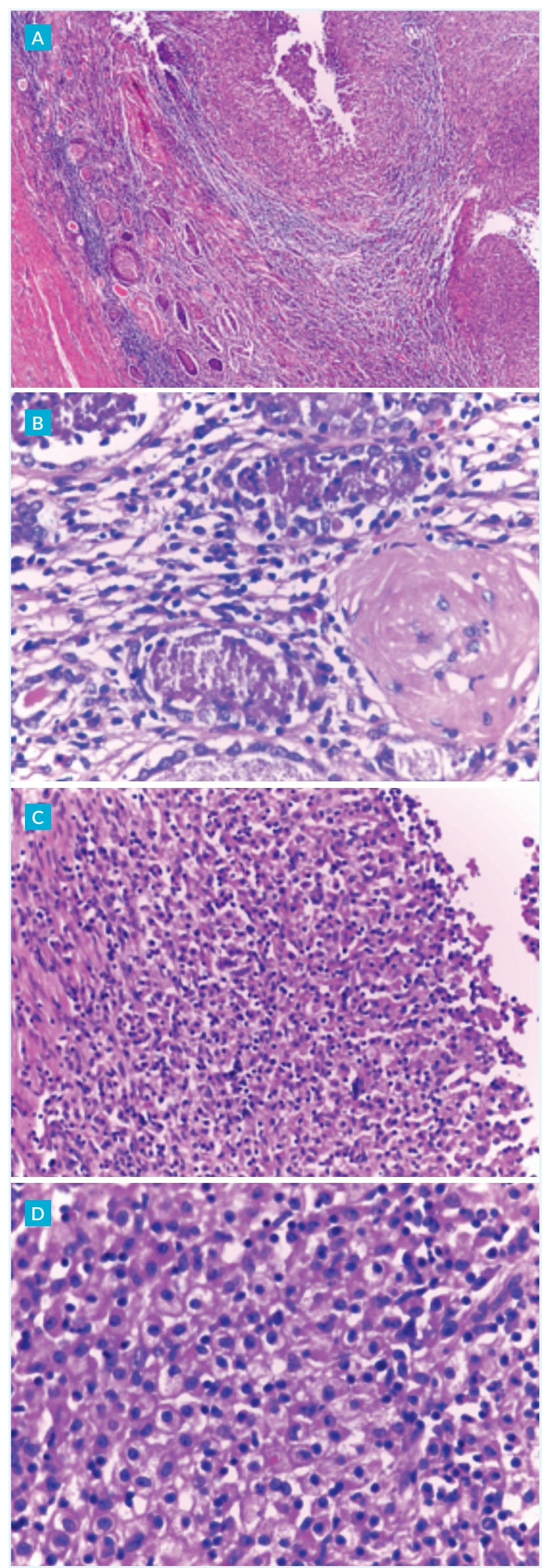

FIGURE 4. Microscopic findings. A/B) Atrophic renal parenchyma and abscess formation. C) Collection of foamy histocytes.

D) Collection of foamy histiocytes surrounded by a necrotic area. 
CONFLICTS OF INTEREST: The authors declare that they have no conflicts of interest.

FINANCIAL SUPPORT: This work has not received any contribution, grant or scholarship.

CONFIDENTIALITY OF DATA: The authors declare that they have followed the protocols of their work center on the publication of data from patients.

PROTECTION OF HUMAN AND ANIMAL SUBJECTS: The authors declare that the procedures followed were in accordance with the regulations of the relevant clinical research ethics committee and with those of the Code of Ethics of the World Medical Association (Declaration of Helsinki).

CONFLITOS DE INTERESSE: Os autores declaram não ter qualquer conflito de interesse na realização do presente trabalho.

FONTES DE FINANCIAMENTO: Não houve qualquer fonte de financiamento na realização do presente trabalho.

CONFIDENCIALIDADE DOS DADOS: Os autores declaram ter seguido os protocolos da sua instituição acerca da publicação dos dados de doentes.

PROTEÇÃO DE PESSOAS E ANIMAIS: Os autores declaram que os procedimentos seguidos na elaboração do presente trabalho estão em conformidade com as normas das comissões de investigação clínica e de ética, bem como da declaração de Helsínquia e da Associação Médica Mundial.

\section{REFERENCES}

1. Chaudhary R, Singh K, Jain N, Biswas R. Chronic flank pain, fever and an unusual diagnosis. BMJ Case Rep. 2011;2011. pii: bcr0820114646.

2. Addison B, Zargar H, Lilic N, Merrilees D, Rice M. Analysis of 35 cases of xanthogranulomatous pyelonephritis. ANZ J Surg. 2015;85:150-3.

3. Gerus S, Apoznański W, Szydelko T, Patkowski D. Pyelonephritis xanthogranulomatosa in a 7-year-old girl. Central Eur J Urol. 2012;65:162-3.

4. Rollino C. Direct Bacterial Infection of the Renal Parenchyma: Pyelonephritis in Native Kidneys. In: Satoskar A, Nadasdy T, editors. Bacterial Infections and the Kidney. Berlin: Springer; 2017.

5. Begum T, Huq M, Ahmed. M Xanthogranulomatous pyelonephritis. BMJ Case Rep. 2016;2016. pii: bcr2016216025.

6. Caliskan S, Özsoy E, Kaba, S, Koca O, Öztürk MI. XanthogranuIomatous Pyelonefritis. Arch Iran Med. 2016;19:712-4.

7. Tan W, Papagiannopoulos D, Elterman L. Bear's pow sign: a classic presentation of xanthogranulomatous pyelonephritis. Urology. 2015;86:e5-e6.

8. Korkes F, Favoretto R, Bróglio, Silva C, Castro M, Perez M. Xanthogranulomatous pyelonephritis: clinical experience with 41 cases. Urology. 2008;71:178-80.
9. Sugie S, Tanaka T, Nishikawa A, Yoshimi N, Kato K, Mori H, et al. Fine-needle aspiration cytology of xanthogranulomatous pyelonephritis. Urology. 1991;37:376-9. 